Teka Kom. Politol. Stos. Międzynar. - OL PAN, 2017, 12/2, 59-84

\title{
FROM CONTINUITY TO BREAKTHROUGH: THE OBAMA ADMINISTRATION'S POLICY IN LATIN AMERICA
}

\author{
Marcin Fatalski \\ Institute of American Studies and Polish Diaspora \\ Jagiellonian University \\ email: marcin.fatalski@uj.edu.pl
}

\begin{abstract}
The election of Barack Obama aroused grand expectations in Latin America. Obama was expected to rejuvenate inter-American relations neglected by George W. Bush's administration. However, the United States no longer sees Latin America as "the most dangerous area in the world." Economic crises and international problems that Obama's administration had to face contributed to Latin America not being a top priority for Washington. One of the first challenges for the new administrations was removal of the Honduran president by the military. The United States adopted pragmatic standpoint and kept the Honduran conflict at a distance - there was no hope of the constitutional president regaining his position, regardless of sanctions or political pressure from Washington. Obama's administration contributed considerably to success of the peace process in Colombia. Stabilizing the situation in Colombia remained one of the security priorities of the Obama administration. It did not limit its activity to Plan Colombia, but took an active part in the peace talks and supported the agreement. Obama administration also expanded the goals of the Mérida Initiative to go beyond traditional, military methods of fighting criminal organizations. US intended to strengthen the rule of law in Mexico. The greatest achievement of this administration was normalization of the relations with Cuba, a truly revolutionary step. It was possible because of the change in the outlook of US public opinion on the matter of normalization, pressure from Latin American countries, and the change in the Cuban regime's approach to the US.
\end{abstract}

Keywords: U.S. Latin American policy, Obama administration, Cuba, Plan Colombia, democracy, Mérida Initiative

\section{INTRODUCTION}

When Barack Obama was inaugurated as President of the United States in 2009, Latin America celebrated. There was a general anticipation that Obama's election would work towards improving Latin America's relations with the US following their decline during the eight years of the George W. Bush presidency. 
Obama, the first African American to serve as president, quite naturally garnered affection in Latin America where previous decades had given rise to the emancipation of indigenous and colored peoples. ${ }^{1}$ Public opinion polls clearly indicated greater approval for the Democratic candidate than for John McCain. While expectations for Obama's administration varied from country to country, they were nonetheless, generally undoubtedly high. ${ }^{2}$

Latin American political elites shared the optimism of the citizens and centrist political leaders were naturally pleased with Obama's election. However, it is also noteworthy that even those political leaders who had opposed the US and criticized the American development models also had high hopes for the Obama administration. Hugo Chávez, president of Venezuela, announced that he hoped for the lifting of US sanctions on Cuba. Fidel Castro complimented Obama's intellectual capacity, however he expressed his doubts whether Obama was truly aware of the international problems he faced. ${ }^{3}$

Latin American public opinion has always favored US presidents who inspired hope and affection. John F. Kennedy remains a compelling example of this. The US ambassador in Argentina in the 1960s recalled, "in my four years in Argentina, I was asked at least once a month to participate in a dedication of a Kennedy school, road or bridge." ${ }^{4}$ Similarly, the fascination with Obama and the hopes that people had for his presidency led to imaginative, sometimes even eccentric, consequences. For instance, some candidates in local elections in Brazil changed their names to 'Barack' or 'Obama' and Boggy Peak, the highest mountain in Antigua and Barbuda, was renamed Mount Obama. ${ }^{5}$

Obama's political affiliation was likely one of the factors behind his appeal. The Democratic Party is perceived as liberal, which in turn implies empathy towards American partners and a more conciliatory attitude towards international politics than would be expected of the Republicans. The Democrats are associated with encouraging democracy and economic aid in Latin America. The Republicans are rather associated with a more pro-business attitude ("depend on trade not aid") and unilateral politics based on power-plays. This view has been

1 Lula da Silva, the president of Brazil, expressed the conviction that Obama's election would play a part in the political and social changes taking place in the Americas: "Just as Brazil elected a metal worker, Bolivia elected an Indian, Venezuela elected Chavez and Paraguay a bishop, I think that it would be an extraordinary thing if, in the largest economy in the world, a black man were elected president of the United States." Quoted in: M. Weisbrot, Obama's Latin American Policy: Continuity Without Change, "Latin American Perspectives" 2011, vol. 38, no 4, p. 63.

2 D. P. Erikson, Obama \& Latin America: Magic or Realism, "World Policy Journal" 2008, vol. 25 , no. 4 , p. 101.

3 Castro's comments on the presidency were made more poignant when the then 82-year-old called McCain "old, bellicose, uncultured, not very intelligent and not in good health.” D. P. Erikson, op. cit., p. 102.

4 Quoted in: S. G. Rabe, The Most Dangerous Area in the World: John F. Kennedy Confronts Communist Revolution in Latin America, Chapel Hill, University of North Carolina Press, 1999, p. 1.

5 D. P. Erikson, op. cit., p. 102. 
criticized by scholars who point out that, besides rhetoric, there is not much of a difference in the foreign policy of the two American parties. They also notice that the effects of the foreign policies of both parties are the same, despite a difference in the methods and aims of different presidents. Those who propagate the view that there has not been much change in US foreign policy towards Latin America point to certain factors fostering continuity, such as the position of the politicians responsible for the policies, the stance of the Congress, and the influence of public opinion and lobbies, including the large Latin American (especially Cuban) diaspora in the US. ${ }^{6}$

Not to go into the details of how the differences in public opinion really express the differences in the policies of the two parties, the hopes that Obama's presidency would deeply rejuvenate inter-American relations seemed exaggerated. Washington no longer sees Latin America as "the most dangerous area in the World," (to use Kennedy's words) as it did during the Cold War, especially during times of crisis. Additionally, long-term political trends and the context in which the new president took office also contributed to Latin America not being a top priority in the 2008 presidential campaign and during Obama's time in office.

The continuous democratization of Latin American countries after the Cold War and their growing economic independence led to a significant decline of American influence in these countries. The reformist left grew in power which led to the election of Inácio Lula da Silva in Brazil, for instance; however, his presidency turned out to be quite moderate. Parties which could be called populist came into power in some countries. The term 'populist' is subject to contention but for the purposes of this paper I will note some characteristics of the governments given this appellation in Latin America. These are leftist governments which endorse the redistribution of gross national income; these governments support marginalized social groups and refer to and play on the hostility between economic and intellectual elites and people lower in the social hierarchy; they refuse to accept the (neo)liberal economic development model. A common denominator of these movements in different countries is their resentment towards the US and the attempt to undermine the dominant position of America. ${ }^{7}$ These factors have limited the US sphere of influence in Latin America.

While Barack Obama criticized the Bush administration's stance on Latin America, mentioning "eight years of the failed policies of the past," and called for the US to gain a position of leadership in the area, he did not actually pay much attention to the region. The only speech he gave addressing the matter was in Miami during a meeting with Cuban-Americans. The then senator Obama criticized the forced 'top-down reform'. He said: "We need an agenda that advances democ-

6 J. Buxton, Forward into History: Understanding Obama's Latin American Policy, "Latin American Perspectives" 2011, vol. 38, no. 4, p. 29-30.

7 See: Ch. Deiwiks, Populism, "Living Reviews in Democracy" 2009, vol. 1, available online: https://www.lrd.ethz.ch/index.php/lrd/article/viewArticle/lrd-2009-3 (accessed on: 30.03.2017). 
racy, security, and opportunity from the bottom up." ${ }^{8}$ As he was campaigning in the Rust Belt, Obama mentioned that it was necessary to renegotiate the NAFTA agreement; however this declaration was for the benefit of the working-class voters and did not result in real effects. ${ }^{9}$

"A New Partnership for the Americas" which was published at that time, gives a deeper look into the position of the then presidential candidate. Among the key challenges for his future policies, the document lists economic growth, global warming, energy security, and the fight against drug trafficking and terrorism. The document promises the reinstatement of the Special Envoy for the Americas, strengthening the State Department on a staff level and widening its influence in the shaping of US policies on Latin America. As a presidential candidate, Barack Obama was in favor of opening a new chapter in relations with Cuba, underlining that this would need to be preceded by a change in the Castro regime. US policy regarding Cuba was to be based on building relationships between the US and the Cuban people, and one of the proposed methods for this was to lift restrictions obstructing Cuban Americans keeping in touch with their families on the island and sending remittances. Obama's postulations were, in effect, a reversal of the five-decade-long US isolation of Cuba.

At the same time, the document states that the embargoes would continue and lists various ways the post-Fidel government, led by his brother Raul, could be assisted in democratizing the state. ${ }^{10}$ Thus Obama formulated a policy on Cuba which had a goal similar to that of his predecessors - to bring democracy to the island. The leading role of the US in this process would serve as a response to the anti-American politics of Hugo Chávez which arose, according to Obama's document, as a reaction to the Bush administration's policies in the area. ${ }^{11}$

Obama also underlined the necessity of combatting the increasing crime rates in Central America and Mexico. This topic appeared during Obama's meetings with Mexican and Columbian leaders, too. ${ }^{12}$ The crime issue is not only related to the trafficking of drugs into the US - the expansion of criminal organizations and the increasing violence had a tangible effect on US security--and Obama saw the fight against crime as one of his top priorities in the region. However, he did not provide any solutions to the problem and only mentioned a "new security initiative with our Latin American neighbors - an initiative that extends beyond Central America." The proposals of the Obama program were merely an elabora-

8 The White House, Obama's Speech on Leadership in the Americas, Speech in Miami, Florida, 23 May 2008, available online: http://www.cfr.org/elections/obamas-speech-leadershipamericas/p16341 (accessed on: 30.03.2017).

9 A. Lowenthal, Fresh Start or False Start? Obama's Partnership Initiative in Latin Ameri$c a$, "The American Interest" 2010, p. 109.

${ }^{10}$ Obama'08, A New partnership for the Americas, 2008, available online: http://obama.3cdn. net/f579b3802a3d35c8d5_9aymvyqpo.pdf (accessed on 30.03.2017).

${ }^{11}$ Ibidem.

${ }^{12}$ D. P. Erikson, op. cit., p. 102. 
tion of already existing mechanisms of inter-American cooperation in the field of fighting crime. Obama also supported the Colombian government's right to act outside its borders in its struggle against terrorism and to employ its military in combating the drug trade. ${ }^{13}$

All of these statements seem conservative. Obama criticized the Bush administration for the deterioration of US relations with Latin America, but it seemed that the main difference was in the importance Obama gave to the issues of Latin America which had been generally disregarded under Bush.

\section{OBAMA ADMINISTRATION POLICIES}

Although Latin America remained in the shadow of other matters during the campaign, Obama had to pay greater attention to the region once he took up office. This was a result of current events as well as the necessity to address systemic issues. Obama's only foreign interlocutor when he was president-elect was Felipe Calderón, the president of Mexico; the first guest at Camp David was Luiz Inácio Lula da Silva. Secretary of State Hillary Clinton and Vice President Joe Biden also met with several Latin American leaders.

Obama proved his interest in Latin America by taking up an active role in the 5th Summit of the Americas in Trinidad and Tobago in April 2009. ${ }^{14}$ Obama made a good impression on Latin American leaders during the summit - his actions, such as shaking Chávez's hand--strengthened the hopes of a more temperate US policy towards the region and irritated the right wing in the US. ${ }^{15}$ Obama's speech, which seemed to confirm the reorientation of US policy, had a great impact. The President admitted that, "the promises of partnership have gone unfulfilled in the past," and, "at times we sought to dictate our terms." He noticed that the US and Latin America had found themselves in a situation which was historically challenging, especially with the specter of the economic crisis looming. Obama demonstrated that he represented a new generation of politicians and declared the will to open a new chapter in inter-American relations. ${ }^{16}$ He listed matters such as battling the economic crisis and building prosperity "from the bottom up" as his top priorities. These entailed directing financial aid towards those most stricken by the crisis in Latin America.

13 Obama'08, A New partnership...

${ }_{14}$ A. F. Lowenthal, op. cit., p. 109.

15 A. Barrionuevo and S. G. Stolberg, Hemisphere's Leaders Signal Fresh Start With U.S., "New York Times" (19 April 2009), p. A6.

16 "I am grateful that President Ortega did not blame me for things that happened when I was 3 months old" in: The White House, Remarks to the Summit of the Americas in Port of Spain, Trinidad and Tobago (17 April 2009), The White House, Public Papers of the Presidents of the United States: Barack Obama, 2009, vol. I, U.S. Government Printing Office, Washington, D.C. 2010, p. 511. 
Obama announced the foundation of the USA Microfinance Growth Fund, which was aimed at providing loans to small and middling entrepreneurs in the countries of the region. He was applauded for saying that, "the United States seeks a new beginning with Cuba." He mentioned the ways collaboration with Cuba had already been facilitated and declared his readiness to cooperate with the Cuban government. ${ }^{17}$ Many people were optimistic upon hearing these declarations, however Obama's first term had eventually disappointing results in the area of US-Cuban relations.

One of the first crises the Obama administration faced was the coup d'etat in Honduras. A specialist in Latin American issues, Michael Shifter, wrote: "No one could have predicted that Honduras, the third-poorest country in the Western Hemisphere, would test the Obama administration's posture toward Latin America, its commitment to multilateralism, and its overarching policy on democracy." 18 This statement is true but with one reservation - the crisis in Honduras had been developing for some time and the situation in which a US intervention would be necessary was to be predicted. On June 28, 2009, the president of the country, Manuel Zelaya, was removed from office by the military and forced to leave Honduras. Roberto Micheletti, the leader of the National Congress, became the interim de facto president according to the constitution of the country, although the deposition of Manuel Zelaya was, of course, illegal.

The coup d'état was the result of a mounting internal conflict in Honduras. Zelaya, who came into power in 2005 as a candidate of the center-right Liberal Party, was seen as a representative of the Honduran establishment. Yet he went through a surprising political metamorphosis during his presidency (it is worth noting that such unanticipated events are quite common in Latin American politics). He became an ally of leftist Latin American countries which had a negative assessment of the US. ${ }^{19}$ There is no clear-cut answer as to what caused the shift in Zelaya's policies but what should remain of greatest interest are the consequences of this shift, i.e. the ultimate rejection of the president by the establishment and the army. Zelaya was accused of violating the constitution of Honduras, probably rightfully so.

Zelaya's deposition led to a situation in which other American countries and international organizations (especially the Organization of American States) were forced to adopt a stance on the unconstitutional appropriation of power by the

${ }^{17}$ Ibidem, p. 511-514.

18 M. Shifter, Obama's Honduras Problem - The United States and Latin America After the Coup, "Foreign Affairs" 24 August 2009, available online: www.foreignaffairs.com/articles/americas/2009-08-24/obamas-honduras-problem (accessed on 06.05.2017).

19 This is a unique example of a right-wing politician changing his views to become a radical leftist. In the democratizing nations of Latin America, leftist politicians who win elections usually change their views to a more central and moderate outlook. See: C. M. Cunha Filho, A. L. Coelho, F. I. Pérez Flores, A Right-to-Left Policy Switch? An Analysis of the Honduran Case under Manuel Zelaya, "International Political Science Review" 2013, vol. 34, no. 5, p. 520. 
interim government. The reaction of international society was resolute and widely shared. The UN, the Organization of American States, the European Union, and ALBA (Bolivarian Alliance for the Peoples of Our America) condemned the coup and called for the reinstatement of the constitutional president. ${ }^{20}$

The situation in Honduras was difficult and important for the US for many reasons. As was mentioned above, after the Cold War Latin American nations were set on a path of continued democratization. This tendency was constant despite a few attempts at overthrowing constitutional governments. Although the US had supported various coups and authoritarian governments in the past, US administrations ultimately always aimed at strengthening the democratic process in Latin America. Support for dictatorships, authoritarian governments or, conversely, for democratic processes, was dependent on how the US defined its interests at any given time. Reinforcing the processes of democratization in Latin American countries became especially important after the end of the Cold War.

The United States' reputation for frequently involving itself in Latin American coups led many political critics in the country to raise the concern that the US was also partly responsible for the 2009 putsch that had ended in the overthrowing of Zelaya. Chávez, one of Zelaya's political allies, was the one who put forward the accusation of US interference in the Honduran crisis. ${ }^{21}$ Indeed, Zelaya's predilection for the rising wave of Latin American populism made him a problem for Washington. ${ }^{22}$ Yet, while Chávez may have believed in US interference in Honduras, there is no evidence that Washington did, in fact, intervene in the Honduran coup.

The Obama administration was faced with an exceptionally complicated issue. From a formal and legal standpoint, the crisis in Honduras was a coup d'état because a legally elected president had been forcibly removed from power. However, as the coup took place with the support of a significant percentage of Hondurans, it revealed profound political polarization in the country. The actions of the military were backed by the majority of the political powers represented in parliament (including Zelaya's own Liberal Party), the High Court, the Attorney General and even the Ombudsman. ${ }^{23}$ This was driven by the general opinion that Zelaya was on his way to taking autocratic control over the country. Fear of the president's populism and of repeating the Venezuelan scenario led many public institutions and organizations to support the military coup. ${ }^{24}$ From the

${ }^{20}$ V. Saranti, A System of Collective Defense of Democracy: The Case of Inter-American Democratic Charter, "Goettingen Journal of International Law" 2011, vol. 3, issue 1, p. 705-707; ALBA Declaration on Honduras Coup d'Etat, 29June 2009, available online: https://venezuelanalysis.com/analysis/4564 (accessed on: 30.03.2017).

${ }^{21}$ T. Padgett, The Honduran Coup. How Should the US Respond? "Time", 29 June 2009.

22 T. Legler, Learning the Hard Way. Defending Democracy in Honduras, "International Journal" 2010, vol. 65, issue 3, p. 608-610.

${ }^{23}$ Ibidem, p. 606.

${ }^{24}$ Ibidem. 
very beginning, deep social divides hindered outside players (other nations and international organizations) from effectively reaching a compromise on the situation in Honduras. Paradoxically, international advocacy for the reinstatement of Zelaya could have served to radicalize the position of those who supported the coup. Especially if diplomatic pressures by means of sanctions and embargoes would have been applied - this may have led the illegitimate government of the country under embargo to gain legitimization by securing national support in the face of outside coercion. These types of actions tend to result in an atmosphere of a besieged fortress and the use of emotional political rhetoric. ${ }^{25}$

The world expected the US to return to a strategy of multilateralism and to the promotion of democratic values in its international policy. With this in mind, it was difficult to imagine that the first crisis the new administration had to face in Latin America would compel the President to reply with Realpolitik. In reaction to the crisis in Honduras, Obama said: "I call on all political and social actors in Honduras to respect democratic norms, the rule of law and the tenets of the Inter-American Democratic Charter. Any existing tensions and disputes must be resolved peacefully through dialogue free from any outside interference." ${ }^{26}$ One could say that this was a stance typical for Obama - firm in terms of adhering to laws and regulations but leaving room for compromise. ${ }^{27}$ This opinion could also be interpreted as one imparting a certain relativity to the dispute.

The US was especially criticized for apparently failing to recognize the events in Honduras as a coup which, in light of American law, has real effects in the way the US is to aid the nation in question. Obama's opponents also disapproved of the fact that the US did not recall its ambassador, that it did not freeze assets belonging to the coup leaders and refrained from instating trade embargoes. ${ }^{28}$ It is worth noting that the administration's actions were also criticized by those who interpreted the events in Honduras and the US reaction through a different lens. US proponents of a firm policy towards leftist Latin American governments refused to view the Honduran events as a putsch and criticized the Obama administration for treating it as such. ${ }^{29}$ The new Honduran government made use of the US Republican support.

${ }^{25}$ S. H. Allen, The Determinants of Economic Sanctions Success and Failure, "International Interaction" 2005, vol. 31, issue 2, p. 123-126. J. Grauvogel and C. von Soest, Claims to Legitimacy Count: Why Sanctions Fail to Instigate Democratisation in Authoritarian Regimes, "European Journal of Political Research" 2014, vol. 53, issue 4, p. 637.

${ }^{26}$ The White House, Statement from the President on the Situation in Honduras, 28 June 2009, in: The White House, Public Papers of the Presidents of the United States: Barack Obama, 2009, op. cit., p. 921

${ }^{27}$ M. Shifter, op. cit.

${ }^{28}$ Latin American Perspectives, Introduction: The Obama Initiative, "Latin American Perspectives" 2011, vol. 38, no. 4, p. 10-11.

29 This was the position of Senator Jim DeMint (R.-S.C.) who, together with some highprofile Cuban Americans, visited Honduras in order to demonstrate his support for the new presi- 
The view that the US refrained from establishing embargoes because it did not acknowledge the Honduran crises as a coup does not fully express the Obama administration's stance on the matter. In light of so-called 'coup provision,' which was reinstated in subsequent acts on US foreign assistance operations, the American government should withdraw aid from a country whose legal government had been overthrown in a military coup d'état. ${ }^{30}$ Contrary to many other regulations on foreign aid, this law does not allow abstaining from embargoes - recognizing the events in Honduras as a coup would have automatically forced the US to withdraw its aid for the country. ${ }^{31}$

The Obama administration could make use of the doubts which arose as to whether the Honduran events were really a military putsch (the situation specified in the act mentioned above) since Zelaya was planning on violating the constitution and was himself deposed by a ruling of the High Court. Following the events, Secretary of State Hillary Clinton desisted from saying whether coup provision would be enacted and the US did not withdraw its aid from the country. However, the US did revoke \$20 million in aid shortly after; although the State Department stressed that this was not a result of statutory obligations. Even when, in 2009, the US withdrew all non-humanitarian aid from Honduras, the Department of State was adamant that this did not imply that a military coup had taken place in the country. ${ }^{32}$

It seems that the policy of Obama's administration should be viewed as an attempt to keep the Honduran conflict at a distance. US policy was pragmatic in this matter - the American policymakers may have viewed the situation as one in which there was no hope of the constitutional president regaining his position, regardless of the application of sanctions or political pressure from Washington. The US attempted to not exacerbate the conflict and tried not to close the way for further negotiation. ${ }^{33}$ Therefore the introduction of sanctions only was meant to force the heads of the new Honduran government to take part in negotiations. At the same time, the US avoided enacting coup provision so that American diplomats had a full range of possible actions.

The US became engaged in hashing out a compromise which would end the crisis in Honduras and a key role was given to the president of Costa Rica. The San Jose Accord entailed the reinstatement of the constitutional president with diminished powers and guaranteed a presidential election in 2009. This accord

dent. C. Sabatini, Rethinking Latin America: Foreign Policy is More Than Development, "Foreign Affairs" 2012, vol. 91, no. 2, p. 9.

${ }^{30}$ Consolidated Appropriations Act, 2008, Pub. L. No. 110-161, Sec. 608 available online: www.gpo.gov/fdsys/pkg/PLAW-110publ161/pdf/PLAW-110publ161.pdf(accessed on 30.03.2017).

${ }^{31}$ Congressional Control of Foreign Assistance to Post-Coup States, "Harvard Law Review" 2014, vol. 127 , no. 8, p. 2500.

32 Ibidem, pp. 2505-2507.

33 Ibidem, p. 2506. 
was signed by both Zelaya and the interim president, however it was only partly enacted. While the election did take place as planned, Zelaya was not allowed to return to office.

US policy in Latin America has been continuously influenced by both economic and political issues. American businesses have a wide range of ventures in many Latin American countries and these are safeguarded by Washington with the help of various foreign policy strategies. Another important factor of US foreign policy in the area is foreign aid--seen as an investment in improving security and development - over the past decades, foreign aid has remained an important tool in US foreign policy kit. The US has also become engaged in new activities in the region. While it was noticed that, for the first time in history, the number of middle-class citizens in Latin American society had surpassed that of citizens living in poverty, it was also clear that these economic and social conditions were unstable and could quickly deteriorate owing to the institutional weakness of Latin American governments, the inefficiency of social systems in these countries (health and education services), and high crime rates (including the drug trade). ${ }^{34}$

Obama's administration wanted to see Latin America as a place of cooperation of American republics in the fields of modernization and democratization. This cooperation was meant to engage, above all, the more 'sensitive' nations, i.e. Guatemala, El Salvador and Honduras, where national systems were endangered by organized crime. The weakness of Latin American states was a problem for the US and the effects of crime and aggression were manifested in migration surges from these regions to the US (including unaccompanied children). ${ }^{35}$ The assumption that solving the problems of the US (illegal immigration) must take place by strengthening the weakest nations in the region was a warranted one, because poverty and crime were the main factors forcing people to migrate to the US.

The US also declared support for the peace process in Colombia (stressing its commitment to close cooperation with the Colombian government). ${ }^{36}$ Colombia is one of the United States' major allies in the region, a result of the domestic issues plaguing the country and the implications these have for the US. The Obama administration inherited and continued one of the key US programs in Latin America - Plan Colombia. This strategy, announced in 1999 as the joint program of the US and Colombian governments, was meant to consolidate and enhance efforts in combating the problems of drug production and trade in the country. This is an issue which has direct consequences in the US, as most of the cocaine produced in Colombia ends up on the American market. Obama took up office in a country which was the biggest cocaine market in the world - the

${ }^{34}$ The White House, National Security Strategy, February 2015, p. 27 available online: https://obamawhitehouse.archives.gov/sites/default/files/docs/2015_national_security_strategy. pdf (accessed on 30.03.2017).

${ }^{35}$ Ibidem, p. 28.

${ }^{36}$ Ibidem. 
US was responsible for $40 \%$ of the world's consumption of this drug, which is imported to the States mainly from Colombia. ${ }^{37}$ This brought about Washington's engagement in combatting the drug trade in this country.

The drug problem had been intensifying since the 1980s, when Colombia stopped being an intermediary in drug trafficking and became a producer. Within the two decades that followed, Colombia became the largest producer of illegal cocaine in the world. ${ }^{38}$ This was exacerbated by the ongoing Colombian civil war between the government and FARC (Revolutionary Armed Forces of Colombia) in the 20th century. However, in the 1980s and 1990s FARC was only superficially engaged in revolutionary rhetoric, the main body of its enterprise was centered on drug trafficking as a means of financing the organization and acts of terror against the government and the people of Colombia. The situation led to the diminishing (and, at times, even disappearance) of the government's power over vast areas of the country, to the emergence of various paramilitary groups, and to the violation of human rights on a large scale.

Plan Colombia entailed training the Colombian armed forces and the police to combat drug production and organized crime. Despite criticism, the plan yielded significant results as the area of coca plantations in Colombia was reduced. Some of the plantations did move to Peru and Bolivia, however the overall area of coca plantations in Latin America did decrease. ${ }^{39}$

Colombia made significant progress in combating organized crime during Álvaro Uribe's presidency, although the presidency, itself, was quite controversial. Even before Obama came into power, the Colombian government undertook to improve the state of human rights in the country as these had been violated severely in the past, even by former governments. As Obama took up office, a new president was also elected in Colombia and Uribe was succeeded by Juan Manuel Santos, the former Minister of Defense. This new president was expected to bring about a change in policy with regards to the internal conflicts in the country. Obama's administration supported the idea of ending civil conflicts by allowing the guerilla movement to take part in the social and political life of the country.

Although the forms of American aid for Colombia were criticized, the US did not restrict the support it was providing the nation during Obama's presidency. Colombia had earlier already become one of the main recipients of American support, however the initiation of Plan Colombia can be seen as a liminal point in the cooperation of the two nations as it implied increased military aid on part

37 UN, World Drug Report 2010, United Nations Office of Drugs and Crime, United Nations Publication, New York 2010, p. 72-74, available online: www.unodc.org/documents/wdr/ WDR_2010/World_Drug_Report_2010_lo-res.pdf (accessed on 30.03.2017).

$\overline{38}$ UN, World Drug Report 2006 , United Nations Office of Drugs and Crime, vol. 2, United Nations Publication, New York 2006, p. 239, available online: www.unodc.org/pdf/WDR_2006/ wdr2006_volume2.pdf (accessed on 30.03.2017).

${ }^{39} \overline{\mathrm{UN}}$, World Drug Report 2010, op. cit., p. 65. For a critique of the program see: J. D. Rosen, The Losing War: Plan Colombia and Beyond, State University of New York Press, Albany 2014. 
of the US. The most significant support was offered within the framework of the International Narcotics Control and Law Enforcement program and by the Narcotics Control fund, which is an expression of the priorities of US policy on Colombia. ${ }^{40}$ As was already noted, a major part of US aid for Colombia was aimed at strengthening security, yet, as in the case of Mexico, this was to be done primarily through assisting national military forces in combatting the production and trade of drugs. ${ }^{41}$

American aid for Colombia was not as substantial as for key nations of the Middle East, however during Obama's time in office Colombia remained one of the primary beneficiaries of US security assistance. At the beginning of Obama's presidency Congress did, in fact, undertake to decrease military aid for Colombia in favor of providing other forms of support. The stance of Congress was motivated by criticism which pointed out that the over-militarization of the country had negative consequences (the violation of human rights) and that the 'Colombianization' of the conflict was happening too slowly. ${ }^{42}$

Stabilizing the situation in Colombia remained one of the security priorities of the Obama administration. In his last year in office (2016), Colombia was to continue to be the leading recipient of US financial assistance in Latin America, although as the conflict de-escalated the focus on military aid lessened. ${ }^{43}$

Plan Colombia was also criticized for lacking efficiency in curbing the amount of drugs that reached the US. Nevertheless, it was successful because it contributed towards preventing civil war in Colombia. The defeat of the guerilla army (perceived as a terrorist organization in the US) by the military was one of the key reasons FARC changed its approach and, in the long term, the reason for the initiation of peace talks. ${ }^{44}$ The military success was by no means a given, because there continued to be a strong governmental faction ardently opposing both negotiation and reaching a compromise with the guerilla (this included former president Uribe).

However, ending the conflict was one of the Obama administration's main goals - ending the civil war and including FARC in political discourse meant that the US significantly reduced the problems connected to Colombian drug trade and production. Obama's administration was not content with mere rhetoric and,

40 P. Fajardo-Heyward, Understanding the Effect of Security Assistance on Human Rights: The Case of Plan Colombia, "The Latin Americanist" 2015, vol. 52, issue 2, p. 8.

${ }^{41}$ USAID, U.S. Overseas Loans and Grants. Obligations and Loan Authorizations, July 1, 1945-September 30, 2015, U.S. Agency for International Development, p. 97 available online: http://pdf.usaid.gov/pdf_docs/PBAAF100.pdf (accessed on 30.03.2017).

42 P. Fajardo-Heyward, op. cit., p. 9.

${ }^{43}$ P. J. Meyer, U.S. Foreign Assistance to Latin America and the Caribbean: Recent trends and FY2016 Appropriations, "Congressional Research Service" 7 January 2016, p. 7, available online: https://fas.org/sgp/crs/row/R44113.pdf (accessed on 30 March 2017); USAID, U.S. Overseas Loans and Grants..., p. 86, 97.

${ }_{44}$ J. S. Beittel, Peace Talks in Colombia, "Congressional Research Service”, 31 March 2015, available online: https://fas.org/sgp/crs/row/R42982.pdf (accessed on 30.03.2017). 
on Santos' request, took active part in the peace talks. Obama selected Bernard Aronson, a diplomat experienced in leading negotiations in Latin America, as the United States Special Envoy for the Colombian Peace Process. He was not to take part in the actual negotiations but to influence both sides in separate meetings. The US emphasized that their support lay with the Santos government. ${ }^{45}$ According to commentators, the US considerably contributed to the talks and, ultimately, to the consensus that was reached between the sides.

For FARC the key issue was the accountability of the 'guerrilleros' in American courts of law, where they were expected to be tried for drug trafficking and other crimes. Colombia had carried out many such extraditions in the past. It was up to the US to refrain from pressuring Santos in this matter as the Colombian president himself stated that: "I don't believe that any guerrilla is going to turn in his weapon only to go and die in a US jail." ${ }^{46}$ Aronson's declaration that extradition would be solely at the discretion of the Colombian government and would not influence relations was a clear marker of Washington's intentions and could have been crucial in reassuring FARC leadership. ${ }^{47}$

Before the final agreement was reached, Washington openly declared the will to support the realization of the peace process. The strategy of foreign aid, which was intended to help the former guerillas join society and ordinary political life, was dubbed 'Peace Colombia.' ${ }^{48}$ Obama mentioned this project in August 2016, when he stressed the importance of the agreement reached by the Santos government and FARC and guaranteed US support in the integration process of Colombia. ${ }^{49}$

Although Plan Colombia's success may have been limited, it was very obvious. However, it had the unexpected outcome of facilitating the development of a drug-trafficking network between the US and Mexico. This led to the flourishing

${ }^{45}$ The White House, Remarks as prepared to the House Foreign Affairs Committee, Subcommittee on the Western Hemisphere, Bernard Aronson, U.S. Special Envoy for the Colombian Peace Process, 24 June 2015, Washington, D.C., available online: http://docs.house.gov/meetings/ FA/FA07/20150624/103679/HHRG-114-FA07-Wstate-AronsonB-20150624.pdf (accessed on 30.03.2017).

46 S. Brodzinsky, The Key to Ending Colombia's Five-Decade Civil War Could be the US, "The Guardian" (19 May 2015) available online www.theguardian.com/world/2015/may/19/colombia-peace-talks-farc-rebels-us-envoy-bernard-aronson (accessed on 30.03.2017).

47 This Time is Different, „The Economist”, 31 October 2015, available online: http:// www.economist.com/news/special-report/21676952-peace-process-could-become-exampleworld-time-different (accessed on 30.03.2017).

48 R. Rampton, Obama Pledges More than \$450 Million Aid to Help Colombia Peace Plan, "Reuters", 5 February 2015, available online: www.reuters.com/article/us-usa-colombia-idUSKCNOVD2XM (accessed on 30.03.2017).

49 The White House, Statement by the President on the Colombia Peace Agreement, $25 \mathrm{Au}-$ gust 2016, available online: https://obamawhitehouse.archives.gov/the-press-office/2016/08/25/ statement-president-colombia-peace-agreement (accessed on 30.03.2017). 
of criminal groups in Mexico which, together with Colombia, is notorious for boasting the fastest development of drug-related criminal activity. ${ }^{50}$

American relations with Mexico remain one of the most complicated issues in US policies towards Latin America. Although relations have for years been overshadowed by disagreements stemming from Mexican immigration to the US as well as immigration from other countries via Mexico, which was caused by the differences in the development of the countries, there is also another reason for tension between the two states. Mexico has been struggling with a ceaseless stream of violence that continues to destabilize the social, economic and political functioning of the country. This violence is the product of criminal activities focused predominantly on the production and trafficking of drugs as well as the trafficking of people. The constant security crisis in Mexico has had an effect on the US and the latter unfortunately continues to contribute to perpetuating the problem. The US is the main point of weapons supply for Mexican criminal organizations.

Mexico answered the rise in criminal activity with the militarization of antidrug policies. The process of militarization came to the fore during Felipe Calderón's presidency. As he took up office, Calderón announced a "war" on drugs which was to be fought against drug-trafficking organizations (DTOs). The aims of the army are different than those of the police so the employment of the military on a broad scale had a significant impact of the "war on drugs." 51

The US entered into a conflict with the drug cartels (DTOs) at Mexico's request. As in the case of Colombia, US engagement came at a time of increased expenditure on security and defense (340\% in Colombia and 125\% in Mexico). ${ }^{52}$ The difference between Plan Colombia and US engagement in Mexico lay, among others, in the reduced influence of the US Department of Defense in the latter case-Mexico was unwilling to agree to the operational engagement of the American Army on Mexican territory.

The cooperation between the US and Mexico was dubbed the Mérida Initiative, because its nature was roughly agreed upon by presidents Bush and Calderón in Mérida in March 2007. The implementing provisions were introduced in the following year.

Before it entered cooperation through the Mérida Initiative, Mexico was not a major beneficiary of American aid in combatting drug-related crime. While

${ }^{50}$ B. Bagley, Drug Trafficking and Organized Crime in the Americas: Major Trends in the Twentieth-First Century. "Woodrow Wilson International Center for Scholars" (Washington D.C., 2012), p. 5, 8, available online: https://www.wilsoncenter.org/sites/default/files/BB\%20Final.pdf (accessed on 01.06.2017).

${ }^{51}$ M. P. Moloeznik, M. E. Suzárez de Garay, El proceso de militarización de la seguridad pública en México (2006-2010)", "Frontera Norte" 2012, vol. 24, no. 48, p. 121-144.

${ }^{52}$ G. C. Delgado-Ramos, S. M. Romano, M. Ortega Bareña, Political-Economic Factors in U.S. Foreign Policy: The Colombia Plan, the Mérida Initiative and the Obama Administration, "Latin American Perspectives" 2011, vol. 38, no. 4, p. 95, 97. 
Mexico was the initiator of the cooperation between the two states, it had earlier been reluctant towards liaising too closely with the US because of the concern over American interference in internal affairs. ${ }^{53}$ In this sense, the Mérida Initiative could be viewed as an organ of US influence or control in Mexico, comparable to similar programs in other Latin American countries. After all, these programs were aimed at formulating strategies of combatting crime and the guerillas which were conceptualized in Washington and which employed American personnel and equipment. There are critics who point to the analogies between this system and that of the Cold War, when American aid in overthrowing dissidents was an element of bolstering US influence.

Therefore aid, such as military or political intervention, is seen as one of the instruments of US hegemony in the area. These critics maintain that a change in rhetoric which came about with the new administration was not accompanied by a genuine change of the US political arsenal in Latin America - including the war on drugs. ${ }^{54}$ Mexico received significant aid from the US between 2008 and 2017. In 2007 the total financial aid equaled $\$ 64.4$ million, only to rise to $\$ 412.5$ million in 2008. In the following years, it remained at this high level. ${ }^{55}$ Once Obama became president in 2011, the program was reevaluated and reshaped and the goals of the Mérida Initiative were augmented. The program was redesigned around four pillars. The first was the war on organized crime; the second, equally important, goal was the development of the rule of law and the protection of human rights in Mexico. The third pillar was the creation of a modern border between the two nations (the "21st Century Border") and the fourth was establishing strong communities which could serve as the foundation for the development of social programs and could stand to face the influence of criminal organizations. The program was agreed upon in May 2013, in Mexico by Obama and the new Mexican president, Peña Nieto. ${ }^{56}$ The redefinition and development of the Initiative's goal should be seen as a step in the right direction. Obama's administration and the Mexican government sought to go beyond traditional, military methods of fighting criminal organizations and decided to try to weaken their infrastructure. The will to strengthen the rule of the law in Mexico was especially significant. This was not the first US effort to undertake cooperation with Latin America using this new method, so it is worth underlining that the US decided to reach for this approach in the case of Mexico despite past failures in the region.

The difficulty in appraising the effectiveness of programs such as the Mérida Initiative has been noticed by commentators. Washington stresses the triumphs of the Initiative, such as capturing cartel leaders (especially Joaquín "El Chapo"

${ }^{53}$ C. Ribando Seelke, K. M. Finklea, U.S. Mexico Security Cooperation: The Merida Initiative and Beyond. Report for Congress, "Congressional Research Service" January 2017, available online: https://fas.org/sgp/crs/row/R41349.pdf (accessed on 18 January 2017), p. 13.

${ }^{54}$ G. C. Delgado-Ramos, S. M. Romano, M. Ortega Bareña, op. cit., p. 95.

${ }_{55}$ C. Ribando Seelke, K. M. Finklea, op. cit., table A-I.

${ }^{56}$ Ibidem, p. 13. 
Guzmán), introducing the accusatorial justice system in Mexico, improving prison standards, and increasing the effectiveness of Mexican border control and supporting its fight with illegal migration (150,000 immigrants from Central America were detained in 2015-2016) ${ }^{57}$ Critics of the program's effectiveness point to the weakness and negligence of the Mexican government in reaching the set objectives. They also highlight the negative effects of the militarization of the war on drugs, the violation of human rights, and corruption. An often quoted example is the murder of 42 students in Iguala, in September, 2014. The Mexican police and justice system proved to be exceptionally indolent in solving the case.

Both Plan Colombia and the Mérida Initiative may lead to the significant reduction of drug trafficking and organized crime in both countries. However, they will not solve the problems connected with drug production and trafficking within the region itself. Criminal activity will continue to flourish in other parts of Latin America (in the Andes and in Central America). Analysts have called the transfer of organized crime to other parts of the region on account of some countries' effective policies the "cockroach effect," because the cartels disperse in the region like cockroaches when someone shines a light on them. ${ }^{58}$

One of the reasons for this is the undiminished demand for illegal drugs in the American and European markets. Moreover, drug consumption in Latin America has also grown significantly in previous years. The growing, worldwide drug market means that the problems of organized crime weakening Latin American states and influencing US security remains one of the greatest challenges Washington faces in Latin America.

The anti-drug policies of the Obama administration were strongly influenced by earlier involvements. The declarations of Obama and of his officials, Gil Kerlikowske, Director of the Office of National Drug Control Policy, and Hillary Clinton indicated that the administration had a negative assessment of the previous war on drugs. However, although certain changes may have been decided upon in Washington, the war on drugs generally remained unchanged in Latin America. ${ }^{59}$ Those who expected a change in the methods of combatting drug trade and trafficking in Latin America under Obama were disappointed. For instance, many were hoping for the halt to the aerial spraying of strong pesticides on illegal coca plantations in Colombia. As examples from both Mexico and Colombia show, Obama's administration worked towards the further militarization of antidrug policies although some of the constituent elements and objectives may have been changed (the US was more dependent on diplomatic methods). Overall, the Obama administration's anti-drug policies, which were set to tackle one of the greatest problems of Obama's presidency, must be given a positive evaluation. Although the policies themselves remain militarized, the administration endeav-

57 Ibidem.

${ }^{58}$ B. Bagley, op. cit., pp. 5, 11.

${ }^{59}$ G. C. Delgado-Ramos, S. M. Romano, M. Ortega Bareña, op. cit., p. 95. 
ored to reach for a more diverse tool-set and to strengthen the national structures and the social unity of the countries most affected by this problem.

The completion of the Colombia's peace talks which were encouraged by the US should be seen as an accomplishment of American foreign policy during Obama's presidency. Just as in the case of normalizing relations with Cuba, this success was conditioned by the evolution of the political situation in a country that the US found extremely important strategically but also by the fact that US policymakers were able to maneuver beyond the bounds of existing conventions.

The normalization of relations with Cuba is seen as one of the main achievements of the Obama presidency. US policy on Cuba since the Cuban Revolution, when Washington severed all ties with Havana and strove for international isolation of the island, may be compared to the US refusal to recognize the People's Republic of China. This analogy led William LeoGrande to state that, "President Barack Obama's historic reversal of half a century of antagonism towards Cuba is reminiscent of Richard Nixon's 1972 opening to China, and will likely be remembered as equally momentous. ${ }^{60}$ This opinion rings true, providing the next administration does not question the normalization policy.

Reorienting US policy towards Cuba was intended to reverse the negative consequences of policy that Obama referred to as the "past five decades" had had. Obama clearly stated that if a policy is not having desired effects, it must be changed - a concept that is difficult to disagree with. Obama's first term in office did not foreshadow the breakthrough that was to happen in US-Cuban relations. On the contrary, it seemed that Obama's declarations from the presidential race, which indicated his readiness to correct US policy towards Cuba, would not result in significant change, and it appeared that his administration was simply going to maintain George W. Bush's strategies.

During Obama's first term his administration only worked on easing the process of sending remittance from Cuban Americans to their families on the island and on liberalizing the restrictions on travelling to Cuba ${ }^{61}{ }^{1}$ However, there were no substantial changes in terms of bilateral cooperation and the status quo in this matter was met with the strong reproach of Latin American nations. The US policy of isolationism was only supported by Latin America in the years directly following the victorious Cuban revolution. As time passed, this policy was less accepted and Washington remained as its lone proponent. As disappointed as Latin American governments were that Obama's predecessors had decided to continue this strategy towards Cuba, they had high hopes that Obama's administration would change the policy.

${ }^{60}$ W. M. LeoGrande, Normalizing US-Cuba Relations: Escaping the Shackles of the Past, "International Affairs" 2015, vol. 91, issue 3, p. 473.

${ }^{61}$ A. F. Lowenthal, op. cit., p. 110. See also: The White House, Statement by the President on Cuba Policy Changes, 17 December 2014, available online: https://obamawhitehouse. archives.gov/the-press-office/2014/12/17/statement-president-cuba-policy-changes (accessed on 30.03.2017). 
During the 6th Summit of the Americas in April, 2012, in Cartagena, Obama was strongly criticized by his Organization of American States partners - including his strongest allies in the region, such as Colombia. The attempts to play down the conflict by American diplomats were not convincing and all of the Latin American nations voted to invite Cuba to the 7th Summit of the Americas in Panama. The firm stance of Latin American nations, which surprised the US President, was, without a doubt, one of the deciding factors (perhaps the most important) that worked towards the change in US policy on Cuba.

Any criticism of the caution or even passivity presented by the Obama administration must take into account that the reorientation of US policy on Cuba was limited by factors inside the US, as well as by the political will of the Cuban regime. It was also strongly affected by historical events which, in the case of Cuba, had an unprecedented influence on US policy. Obama himself noticed that the severance of mutual relations between the US and Cuba was a relic of the Cold War. Moreover, it was sorely unjustified as the US maintained relations with both communist China and Vietnam - the latter a country which came to symbolize Cold War hostility. ${ }^{62}$

There is no doubt that the US strategy of not recognizing and placing embargoes upon Cuba that started in the 1960s was one of the axioms of US foreign policy. None of the political powers in the US had the courage to question the sense of this course of action although it was clearly ineffective. During the Cold War, Cuba's isolation was triggered as a reaction to Castro's policy of exporting revolution and so, did find justification. However, even then, the US policy on Cuba was brought into question. If embargoes fail to accomplish anything in the short term, it is very unlikely that they will do so in the long term. ${ }^{63}$ Liberals observed that not only was the US policy of isolating Cuba unsuccessful but it also had negative effects on the general US policy on all of Latin America. ${ }^{64}$

Yet, American politicians insisted on retaining their firm stance towards Cuba. The Republican Party was the most vocal advocate of this approach - they underlined the strongly anti-communist nature of their position and rejected the possibility of normalizing relations with Cuba. Anti-communism was also the driving force behind the Democrats' position, which they treated as a test of their own credibility in the domestic arena. ${ }^{65}$

Once the Cold War was over, internal affairs played a key role in maintaining the Cuba policy. Just as in the past, an important role in shaping and up-keeping the policy was played by the anti-Castro Cuban diaspora, living mainly in Florida. This is one of the most politically important states in the US and is counted as

${ }^{62}$ The White House, Statement by the President on Cuba Policy Changes, op. cit.

${ }^{63}$ S.H. Allen, op. cit.

${ }^{64}$ Liberals underlined the importance of normalizing US-Cuba relations as early as in the 1980s, as Reagan's anti-communist offensive swept through Latin America. See: W. M. LeoGrande, A Party Divided and Paralyzed, "The Nation", 24 October 1988, p. 395.

${ }^{65}$ W. M. LeoGrande, A Party Divided... 
one of the so-called swing states. Both Republican and Democrat representatives of Florida in the Capitol feared losing the support of this important state, which had voters with Cuban roots and well-defined political views. ${ }^{66}$ It is worth noting that the Democratic position on Cuba was heterogeneous and part of the party has always been for the normalization of relations with Havana. ${ }^{67}$

Under these circumstances the change of the Cuban diaspora's position on the matter had a significant influence on the adjustment of US policy towards Havana. After the revolution Cuban Americans were strong advocates of an iron-fisted approach to the Cuban regime. The Cuban American National Foundation, which comprises a community of conservative, anti-Castro, Cuban Americans, played a central role in shaping US policy. Considerable funds allowed this organization to manipulate the mechanisms of American politics in order to meaningfully influence US policy and render the normalization of relations with Cuba impossible from the 1980s until 2008. ${ }^{68}$ The will to maintain the embargoes placed on the island was based on a belief expressed by many Republicans - that normalization would prolong the existence on the communist regime despite its various economic problems, whereas embargoes and sanctions were expected to utterly destroy the Cuban economy and, in consequence, the political system. ${ }^{69}$

However, during Obama's presidency, there came a change in the outlook of Cuban Americans on the matter; this was in tune with earlier observed trends. Surveys from the early 1990s showed that a vast majority of the Cuban diaspora (87\%) supported the embargo. Yet over time the number of Cuban Americans who could not see the purpose of the US policy and were in favor of lessening restrictions grew. The change in judgment stemmed from the demographic transformation that the diaspora had been experiencing - the first emigrants who surged from Cuba to the US were motivated by politics whereas the migrants from the 1980s and later were motivated by economics. The later immigrants were also adamant about preserving their relationships with family on the island. These factors affected the position of Cuban Americans and, in consequence, the importance of the Cuban diaspora in the American political system. ${ }^{70}$ The Cuban lobby could no longer influence the Washington elites the way it had in the past because the expectations of Cuban Americans had changed.

Castro's regime survived the Cold War and the fall of its ally, the USSR. Cuba felt the loss of foreign aid from Moscow like a blow - it was forced to aban-

${ }^{66}$ The Economist, If Not Now, When?, "The Economist", 5 April 2014, available online: www.economist.com/news/leaders/21600117-would-be-especially-good-time-change-americas-relations-cuba-if-not-now (accessed on 12.06.2017).

${ }^{67}$ W. M. LeoGrande, A Party Divided and Paralyzed, op. cit., p. 395-397.

${ }^{68}$ Idem, Normalizing US-Cuba Relations..., p. 476.

${ }^{69}$ J. Azel, The New Cuba Policy: Fallacies and Implications, "World Affairs" 2015, vol. 178, issue 3, p. 21-27.

${ }^{70}$ W. M. LeoGrande, Normalizing US-Cuba relations: escaping the shackles of the past, op. cit., p. 478. 
don the idea of exporting revolution and had to cease supporting revolutionaries around the world. ${ }^{71}$ Ultimately, the regime gained the support of Venezuela under Hugo Chávez, however financial aid from this country was not able to sustain the underdeveloped and inefficient Cuban economy, which was overwhelmed by systemic failure. Therefore, the change in the Cuban regime's approach to the US was conditioned by a failing economy and a pessimistic view on how to solve this crisis in isolation. There is no doubt that the economic troubles in Venezuela, which led to the shrinking of Venezuelan aid, also influenced the Cuban regime's stance on the US.

The close relationship between Cuba and Venezuela had been one of the pivotal factors in the balance of power between the US and Latin America. As mentioned above - Cuba would not have endured the fall of the USSR without Venezuela's support. Chávez's backing undeniably allowed the Cuban regime to refrain from reform and liberalization. Although the relationship between Havana and Caracas was asymmetric and Cuba was more dependent on Venezuela, Chávez also reaped some benefits - the alliance with Cuba led to the dogmatization of Venezuelan policy and strengthened its anti-American nature. The close cooperation of the two countries created various hurdles for US policy in Latin America so Washington sought to weaken the alliance between Havana and Caracas. It was rightly assumed that reducing financial aid for Cuba would strengthen the conciliatory tendencies in Cuba's foreign policy and be conducive to the liberalization of the government. ${ }^{72}$

The change of head of state was a defining circumstance which led Cuba to adopt a pragmatic attitude towards the US. Raul, who was willing to begin negotiations with Washington, replaced the uncompromising Fidel. It is difficult to know how strongly Cuban policy was influenced by genuine divergences in the viewpoints of Fidel and his brother. Nevertheless, it can certainly be said that a change in policy became possible only after Raul Castro's inauguration as president.

Both Washington and Havana agreed that normalizing relations after fifty years of animosity was necessary and negotiations began. An important role in these was played by Canadian diplomats who had worked towards moderating the conflict since the 1960s. From 2013, the Canadian government co-organized seven confidential meetings between the US and Cuba. Simultaneously, Secretary of State John Kerry met with the chief Cuban diplomat, Bruno Rodriguez. The Vatican also had a part in the negotiations. ${ }^{73}$

The exchange of prisoners was one of the main bones of contention. This issue, which seemed minor in light of the breakthrough that engaging in mutual re-

71 Ibidem, p. 476.

${ }^{72}$ H. A. Trinkunas, T. Piccone, The Cuba-Venezuela Alliance: The Beginning of the End? "Latin America Initiative Policy Brief", The Brookings Institutions, Washington, D.C. 2014.

${ }^{73}$ P. Kornbluh, W. M. LeoGrande, Cuba Confidential, "Mother Jones" 2015, vol. 40, issue 5, p. $44-61$. 
lations was expected to be, turned out to be an obstacle which halted negotiations. The US made a bid to secure the freedom of Allan Gross who had been arrested in Cuba in 2009 and sentenced for espionage. However, Washington rejected the Cuban offer of exchanging Gross for three Cubans arrested in the US and called it disproportionate. This was one of the central controversies of the negotiations between the two nations and only a solution could lead to the normalization of mutual relations. Once a compromise was reached (Gross was freed, among others) a breakthrough in US-Cuban relations became possible. ${ }^{74}$

Obama announced a reorientation in US-Cuban relations in December 2014. The very way in which this was done was unprecedented as the presidents of both nations addressed their citizens at the same time (December 17 - "D17"), declaring that a new chapter in the nations' relations had begun. Obama criticized the strategy of the preceding 55 years and said it "has failed to advance our interests." He indicated that US policy towards Cuba had been shaped by the realities of the Cold War and its aim was to "promote democracy." However, "though this policy has been rooted in the best of intentions, no other nation joins us in imposing these sanctions, and it has had little effect ...." The normalization announced by Obama was to entail establishing diplomatic relations, removing Cuba from the list of countries promoting terrorism, reducing restrictions connected to travel, trade, telecommunication and financial services. ${ }^{75}$

The process of normalization was symbolized by permitting Americans to bring Cuban cigars and rum back to the US. The normalization of US-Cuban relations was met with the enthusiastic reaction of Cubans expecting the improvement of living conditions. While the communist ideology still has a strong presence in society, there is a general conviction that actions must be undertaken to improve living conditions ("no se puede comer la politica.") $)^{76}$

\section{CONCLUSIONS}

As a presidential candidate, Obama criticized Bush for neglecting Latin American issues. This neglect was caused by excessive resources being committed to the war in Afghanistan and Iraq. ${ }^{77}$ This same neglect was not to be found in the Obama administration although it had to rise to the challenges of withdrawing troops from Iraq and fighting the worst financial crisis since the Great Depression. It cannot be said that these, or any other matters, overshadowed Latin American issues - simply put, this part of the world had generally lost much if its significance from Washington's point of view after the end of the Cold War, once the

\footnotetext{
${ }^{74}$ P. Kornbluh, A New Deal With Cuba, "The Nation" 2015, vol. 300, issue 2/3, p. 4-8.

75 Statement by the President on Cuba Policy Changes, op. cit.

${ }^{76}$ Ibidem; P. Kornbluh, A New Deal With Cuba ..., p. 5.

${ }^{77}$ Obama'08, A New partnership...
} 
balance of power had shifted on an international level and political situation in Latin America had changed.

Obama's first term in office disappointed those who expected a significant breakthrough in inter-American relations. When asked about the difference between Bush and Obama, Evo Morales ironically answered: "If something is changed, it's just the color of the president that's changed." ${ }^{\text {" }} 8$ Regardless of the context in which this was said, it expressed the general view of the Latin American left on Obama's presidency (not just that of Chávez supporters.) Liberal and progressive communities in the US also noticed that Obama's policy simply marked a continuation of that of his predecessor - only the rhetoric had changed.

However, Barack Obama could not initiate a revolutionary upheaval in US policy on Latin America and this was never actually his intention. The corrections in US policy in the region that he had announced were meant to guarantee a partnership between the US and Latin American nations. In light of Washington's limited possibilities of influencing the region, it was decided that solving common issues such as drug trafficking and illegal migration should be done in collaboration.

The US stances on the coup in Honduras and on Cuba were both based on the same principle of political pragmatism. This approach in the case of Honduras was bitingly criticized within the US as well as in Latin America, because it was maintained despite an unconstitutional change of head of state. Establishing relations with Cuba, however, was met with widespread approval throughout the Western hemisphere. In this second case, Obama went against the policy of isolating Cuba, accepted by political elites of both parties, a policy which had also isolated the United States at the beginning of the 21st century.

During Barack Obama's two terms in office, US policy was managed in the face of rapidly changing political realities and during an economic crisis. Although Latin America was not one of the top issues the new administration needed to tackle, Obama, influenced by various factors such as the demands of Latin American nations, managed to truly end the Cold War in Latin America by normalizing US relations with Cuba. He did not radically change his predecessors' policy in other areas such as combating the drug trade and illegal migration. Perhaps such a change was not even possible. Overall, Obama's policy in the region must be evaluated positively as it did lead to the US extending its cooperation with its partners in the Organization of American States and to a real breakthrough in relations with Cuba.

${ }^{78}$ Democracynow.org, Bolivian President Evo Morales on President Obama: "I Can't Believe a Black President Can Hold So Much Vengeance Against an Indian President”, 23 April 2010, available online: www.democracynow.org/2010/4/23/bolivian_president_evo_morales_to_ president (30.03.2017). 


\section{Tytul: Od ciągłości do przełomu: polityka Obamy w Ameryce Łacińskiej}

Streszczenie: Wybór Baracka Obamy wzbudziły wielkie oczekiwania w Ameryce Łacińskiej. Oczekiwano, że Obama odnowi stosunki międzyamerykańskie zaniedbane przez administrację George'a W. Busha. Jednak Stany Zjednoczone już nie postrzegają Ameryki Łacińskiej jako „najbardziej niebezpiecznego obszaru na świecie". Kryzys gospodarczy i problemy międzynarodowe, z którymi administracja Obamy musiała się zmierzyć, przyczyniły się do tego, że Ameryki Łacińskiej nie stała się priorytetem w polityce Waszyngtonu. Jednym z pierwszych wyzwań dla nowej administracji było usunięcie przez wojsko prezydenta Hondurasu. Stany Zjednoczone przyjęły w tej sprawie pragmatyczne stanowisko i trzymały się od niej z daleka. gdyż nie było nadziei, że konstytucyjny prezydent odzyska swoje stanowisko niezależnie od sankcji lub presji politycznej Waszyngtonu. Administracja Obamy przyczyniła się znacząco do sukcesu procesu pokojowego w Kolumbii. Stabilizowanie sytuacji w tym państwie pozostawało jednym z priorytetów polityki bezpieczeństwa administracji Obamy. Polityka ta nie ograniczała się realizacji planu Colombia, lecz oznaczała też czynny udział w rozmowach pokojowych i wsparcie porozumienie. Administracja Obamy rozszerzyła także cele programu Mérida Initiative wykraczając poza tradycyjne, wojskowe metody walki z organizacjami przestępczymi. USA zamierzały wzmocnić rząd prawa w Meksyku. Największym osiągnięciem tej administracji jest normalizacja stosunków z Kubą, był to prawdziwie rewolucyjny krok. Stało się to możliwe ze względu na zmianę poglądów opinii publicznej w Stanach Zjednoczonych na temat normalizacji, presji ze strony państw Ameryki Łacińskiej oraz zmiany podejścia kubańskiego reżimu wobec USA.

Slowa klucze: Polityka latynoamerykańska Stanów Zjednoczonych, administracja Obamy, Kuba, plan Colombia, demokracja, program Mérida Initiative

\section{BIBLIOGRAPHY}

1. ALBA Declaration on Honduras Coup d'Etat (29June 2009), available online: https://venezuelanalysis.com/analysis/4564 (accessed on 30.03.2017).

2. ALLEN S. H., 2005: The Determinants of Economic Sanctions Success and Failure, "International Interaction", vol. 31, issue 2.

3. AZEL J., 2015: The New Cuba Policy: Fallacies and Implications, "World Affairs", vol. 178, Issue 3.

4. BAGLEY B., 2012: Drug Trafficking and Organized Crime in the Americas: Major Trends in the Twentieth-First Century. "Woodrow Wilson International Center for Scholars", Washington D.C., available online: https://www.wilsoncenter.org/sites/default/files/BB\%20Final.pdf (accessed on 01.06.2017).

5. BARRIONUEVO A., STOLBERG S.G., 2009: Hemisphere's Leaders Signal Fresh Start With U.S., "New York Times" 19 April, p. A6.

6. BEITTEL J.S., 2015: Peace Talks in Colombia, "Congressional Research Service", 31 March, available online: https://fas.org/sgp/crs/row/R42982.pdf (accessed on 30.03.2017).

7. BRODZINSKY S., 2015: The Key to Ending Colombia's Five-Decade Civil War Could be the US, "The Guardian", 19 May, available online www.theguardian.com/world/2015/may/19/ colombia-peace-talks-farc-rebels-us-envoy-bernard-aronson (accessed on 30.03.2017).

8. BUXTON J., 2011: Forward into History: Understanding Obama's Latin American Policy, "Latin American Perspectives", vol. 38, no. 4.

9. CONGRESSIONAL CONTROL OF FOREIGN ASSISTANCE TO POST-COUP STATES, 2014: "Harvard Law Review", vol. 127, no. 8. 
10. CONSOLIDATED APPROPRIATIONS ACT, 2008, Pub. L. No. 110-161, Sec. 608 available online: www.gpo.gov/fdsys/pkg/PLAW-110publ161/pdf/PLAW-110publ161.pdf (accessed on 30.03.2017).

11. CUNHA FILHO C. M., COELHO A. L., PÉREZ FLORES F. I.,2013: A Right-to-Left Policy Switch? An Analysis of the Honduran Case under Manuel Zelaya, "International Political Science Review", vol. 34, no. 5.

12. DEIWIKS Ch., 2009: Populism, "Living Reviews in Democracy" 2009, vol. 1, available online: https://www.lrd.ethz.ch/index.php/lrd/article/viewArticle/lrd-2009-3 (accessed on 30.03.2017).

13. DELGADO-RAMOS G. C., ROMANO S. M., ORTEGA BAREÑA M., 2011: Political-Economic Factors in U.S. Foreign Policy: The Colombia Plan, the Mérida Initiative and the Obama Administration, "Latin American Perspectives", vol. 38, no. 4.

14. DEMOCRACYNOW.ORG, 2010: Bolivian President Evo Morales on President Obama: "I Can't Believe a Black President Can Hold So Much Vengeance Against an Indian President", 23 April, available online: www.democracynow.org/2010/4/23/bolivian_president_evo_morales_to_president (accessed on 30.03.2017).

15. THE ECONOMIST, 2015: This Time is Different, „The Economist”, 31 October, available online: http://www.economist.com/news/special-report/21676952-peace-process-could-becomeexample-world-time-different (accessed on 30.03.2017).

16. THE ECONOMIST, 2014: If Not Now, When?, "The Economist", 5 April, available online: www.economist.com/news/leaders/21600117-would-be-especially-good-time-change-americas-relations-cuba-if-not-now (accessed on 12.06.2017).

17. ERIKSON D.P., 2008: Obama \& Latin America: Magic or Realism, "World Policy Journal", vol. 25 , no. 4.

18. FAJARDO-HEYWARD P., 2015: Understanding the Effect of Security Assistance on Human Rights: The Case of Plan Colombia, "The Latin Americanist", vol. 52, issue 2.

19. GRAUVOGEL J., VON SOEST C., 2014: Claims to Legitimacy Count: Why Sanctions Fail to Instigate Democratisation in Authoritarian Regimes, "European Journal of Political Research", vol. 53 , issue 4.

20. KORNBLUH P., 2015: A New Deal With Cuba, "The Nation", vol. 300, issue 2/3.

21. KORNBLUH P., LEOGRANDE W.M., 2015: Cuba Confidential, "Mother Jones", vol. 40, issue 5.

22. LATIN AMERICAN PERSPECTIVES, 2011: Introduction: The Obama Initiative, "Latin American Perspectives", vol. 38, no. 4.

23. LEGLER T., 2010: Learning the Hard Way. Defending Democracy in Honduras, "International Journal", vol. 65 , issue 3.

24. LEOGRANDE W.M., 1988: A Party Divided and Paralyzed, "The Nation", 24 October.

25. LEOGRANDE W.M., 2015: Normalizing US-Cuba Relations: Escaping the Shackles of the Past, "International Affairs" 2015, vol. 91, issue 3.

26. LOWENTHAL A., 2010: Fresh Start or False Start? Obama's Partnership Initiative in Latin America, "The American Interest".

27. MEYER P.J., 2016: U.S. Foreign Assistance to Latin America and the Caribbean: Recent trends and FY2016 Appropriations, "Congressional Research Service" 7 January, available online: https://fas.org/sgp/crs/row/R44113.pdf (accessed on 30 March 2017).

28. MOLOEZNIK M.P., SUZAREZ DE GARAY M.E., 2012: El proceso de militarización de la seguridad pública en México (2006-2010)", "Frontera Norte", vol. 24, no. 48.

29. OBAMA'08, 2008: A New partnership for the Americas, available online: http://obama.3cdn. net/f579b3802a3d35c8d5_9aymvyqpo.pdf (accessed on 30.03.2017) 
30. PADGETT T., 2009: The Honduran Coup. How Should the US Respond? "Time" 29 June.

31. RABE S.G., 1999: The Most Dangerous Area in the World: John F. Kennedy Confronts Communist Revolution in Latin America, Chapel Hill, University of North Carolina Press.

32. RAMPTON R., 2015: Obama Pledges More than $\$ 450$ Million Aid to Help Colombia Peace Plan, "Reuters", 5 February, available online: www.reuters.com/article/us-usa-colombia-idUSKCNOVD2XM (accessed on 30.03.2017).

33. RIBANDO SEELKE C., FINKLEA K.M., 2017: U.S. Mexico Security Cooperation: The Merida Initiative and Beyond. Report for Congress, "Congressional Research Service", January, p. 13, available online: https://fas.org/sgp/crs/row/R41349.pdf (accessed on 18 January 2017).

34. ROSEN J.D., 2014: The Losing War: Plan Colombia and Beyond, Albany, State University of New York Press.

35. SABATINI C., 2012: Rethinking Latin America: Foreign Policy is More Than Development, "Foreign Affairs", vol. 91, no. 2.

36. SARANTI V., 2011" A System of Collective Defense of Democracy: The Case of Inter-American Democratic Charter, "Goettingen Journal of International Law", vol. 3, issue 1.

37. SHIFTER M., 2009: Obama's Honduras Problem - The United States and Latin America After the Coup, "Foreign Affairs" 24 August, available online: www.foreignaffairs.com/articles/ americas/2009-08-24/obamas-honduras-problem (accessed on 06.05.2017).

38. TRINKUNAS H. A., PICCONE T., 2014: The Cuba-Venezuela Alliance: The Beginning of the End? "Latin America Initiative Policy Brief" Washington, DC, The Brookings Institution.

39. UN, 2006: World Drug Report 2006, United Nations Office of Drugs and Crime, vol. 2, United Nations Publication, available online: www.unodc.org/pdf/WDR_2006/wdr2006_volume2.pdf (accessed on 30.03.2017).

40. UN, 2010: World Drug Report 2010, United Nations Office of Drugs and Crime, United Nations Publication, New York 2010, available online: www.unodc.org/documents/wdr/WDR 2010/ World_Drug_Report_2010_lo-res.pdf (accessed on 30.03.2017).

41. USAID, 2015: U.S. Overseas Loans and Grants. Obligations and Loan Authorizations, July 1, 1945-September 30, 2015, U.S. Agency for International Development, available online: http:// pdf.usaid.gov/pdf_docs/PBAAF100.pdf (accessed on 30.03.2017).

42. WEISBROT M., 2011: Obama's Latin American Policy: Continuity Without Change, "Latin American Perspectives", vol. 38, no 4.

43. THE WHITE HOUSE, 2008: Obama's Speech on Leadership in the Americas, Speech in Miami, Florida (23 May 2008), available online: http://www.cfr.org/elections/obamas-speech-leadership-americas/p16341 (accessed on 30.03.2017).

44. THE WHITE HOUSE, 2010a: Remarks to the Summit of the Americas in Port of Spain, Trinidad and Tobago (17 April 2009). In: Public Papers of the Presidents of the United States: Barack Obama, 2009, vol. I, Washington, DC, U.S. Government Printing Office.

45. THE WHITE HOUSE, 2010b: Statement from the President on the Situation in Honduras (28 June 2009). In: Public Papers of the Presidents of the United States: Barack Obama, 2009, vol. I, Washington, DC, U.S. Government Printing Office.

46. THE WHITE HOUSE, 2014: Statement by the President on Cuba Policy Changes (17 December), available online: https://obamawhitehouse.archives.gov/the-press-office/2014/12/17/ statement-president-cuba-policy-changes (accessed on 30.03.2017).

47. THE WHITE HOUSE, 2015a: National Security Strategy, available online: https://obamawhitehouse.archives.gov/sites/default/files/docs/2015_national_security_strategy.pdf (accessed on 30.03.2017). 
48. THE WHITE HOUSE, 2015b: Remarks as prepared to the House Foreign Affairs Committee, Subcommittee on the Western Hemisphere, Bernard Aronson, U.S. Special Envoy for the Colombian Peace Process, Washington, D.C., (24 June), available online: http://docs.house. gov/meetings/FA/FA07/20150624/103679/HHRG-114-FA07-Wstate-AronsonB-20150624.pdf (accessed on 30.03.2017).

49. THE WHITE HOUSE, 2016: Statement by the President on the Colombia Peace Agreement, 25 August, available online: https://obamawhitehouse.archives.gov/the-press-office/2016/08/25/ statement-president-colombia-peace-agreement (accessed on 30.03.2017). 